\title{
水酸化第一鉄沈殿による二価金属イオンの共沈
}

\author{
岡 本祥一・岡 本敞子 \\ (理化学研究所)
}

\begin{abstract}
水酸化第一鉄沈殿は, 沈殿生成の際に水溶液中に共存する多くの重金属イオンを共沈除去し, 水 質を浄化する作用が強い, 共沈機構は, $\mathrm{CdI}_{2}$ 型の水酸化第一鉄結晶への各種金属イオンの置換固 溶である場合 $\left(\mathrm{Mg}^{2+}, \mathrm{Zn}^{2+}, \mathrm{Cd}^{2+}, \mathrm{Mn}^{2+}, \mathrm{Co}^{2+}, \mathrm{Ni}^{2+}\right)$ もあるが, $\mathrm{Hg}^{2+}$ および $\mathrm{Cu}^{2+}$ の場合に は, 酸化還元反応が優先する新しい共沈機構によることが明らかとなった. 水酸化第一鉄沈殿の酸 化の機構について, 沈殿結晶の固液界面における酸化反応の生ずる位置が異なるため反応生成物が 異なると考え, topotactic な酸化と, 溶解析出を伴ら酸化とに区別して, 新しい共沈機構について 考察を加えた.

$(6 / 7 / 1977$ 受付 $)$
\end{abstract}

\section{Coprecipitation of Divalent Metal Ions in Solution by Ferrous Hydroxide Gel Formation}

\author{
Shoichi OKAMOTO and Shoko I. OKAMOTO \\ (The Institute of Physical and Chemical Research, Wako-shi, 351)
}

\begin{abstract}
Ferrous hydroxide gel was found to be very efficient for removing various divalent metal ions in solution by coprecipitation. The coprecipitates were ferrimagnetic themselves or can easily be oxidized into ferrimagnetic oxides or hydroxides. The coprecipitation was proposed to be caused by (1) the formation of solid solution $\left(\mathrm{Mg}^{2+}, \mathrm{Zn}^{2+}, \mathrm{Cd}^{2+}\right.$, $\mathrm{Mn}^{2+}, \mathrm{Co}^{2+}$ and $\mathrm{Ni}^{2+}$ ), and (2) the redox reaction with the results of the formation of insoluble solids $\left(\mathrm{Hg}^{2+}\right.$ and $\left.\mathrm{Cu}^{2+}\right)$. The mechanism of the coprecipitation accompanied by the redox reaction is discussed in connection with ionic processes at the ferrous hydroxide crystal-solution interface.

[Received June 7, 1977]
\end{abstract}

\section{1. 緒言}

第一鉄塩あるいは第二鉄塩の水溶液の加水分解によ り，それぞれ水酸化第一鉄あるいは水酸化第二鉄の沈殿 が析出する. 前者は六角板状微結 晶 $\left(\mathrm{CdI}_{2}\right.$ 型) から成 る白色沈殿であるが，後者は非晶性の超微粒子から成る 赤褐色の沈殿である.この非晶性水酸化第二鉄沈殿は， 沈殿析出の際に, 水溶液中に共存する微量の, 様々な重 金属イオンを共沈除去する作用, つまりスカベンジャー としての作用が強い.この作用は古くから分析化学の分 野で微量の重金属イオンの濃縮分離に利用されている. そしてその共沈機構についても検討されている11.

水酸化第二鉄の非晶性沈殿は, 室温付近で超常磁性的 な挙動を示し, $10 \mathrm{kOe}$ の磁場中で $2 \sim 3 \mathrm{emu} / \mathrm{g}$ の磁化 が観測される*. 最近の磁気分離技術の発展を前提とす れば, この程度の弱い磁性体でも磁気分離は可能であろ らから, 水酸化第二鉄沈殿は磁性スカベンジャーとして
の効用が期待される ${ }^{2), 3)}$. 水酸化第二鉄沈殿の共沈機構 は，上述のように沈殿粒子が超微粒状であることによる 強い吸着作用と, その非晶質構造に起因する吸蔵作用々 が支配的と考えられる.これに加えて，共沈イオンの大 きさが $\mathrm{Fe}^{3+}$ のそれと同程度である場合 $\left(\mathrm{Al}^{3+}, \mathrm{Cr}^{3+}\right.$ な ど)，非晶質固溶体の生成も考えて良いものと思われる.

一方水酸化第一鉄も，水酸化第二鉄のスカベンジャ一 作用に劣らずに，その沈殿析出の際に水溶液中に共存す る様々の重金属イオンを共沈除去する作用が強い。それ にもかかわらず，その共沈機構に関する文献が見当たら ない. $\mathrm{Mg}^{2+}, \mathrm{Zn}^{2+}, \mathrm{Cd}^{2+}, \mathrm{Mn}^{2+}, \mathrm{Co}^{2+}$ および $\mathrm{Ni}^{2+}$ な ど, イオン半径 $0.6 \sim 1 \AA$ の 2 価金属イオンに対する水

* 水酸化第二鉄の非晶性沈殿は, $T_{\mathrm{N}} \simeq 450 \mathrm{~K}$ の反強磁性体で あるうと推定される.しかし個々の粒子が極めて小さい(直 径 $45 \AA$ 程度) ため, 単磁区粒子中に含まれる磁性イオン の数の平方根に比例する自発磁化を示すものと考えられる. 
酸化第一鉄の共沈機構は, 置換固溶によるものと著者ら は判断している.この判断の根拠は, 例えば $\mathrm{Ni}(\mathrm{OH})_{2}-$ $\mathrm{Fe}(\mathrm{OH})_{2}$ 二元系において, 格子定数の組成変化が全域 にわたってほぼVegard 則を満たすこと, また上記 6 種 の金属イオンを含む水酸化第一鉄共沈体を, 過酸化水素 や酸素ガスの注入により topotactic に酸化すると, こ れら各金属イオンの $\delta-\mathrm{FeOOH}$ 置換固溶体が得られる ことの 2 点にある ${ }^{4)}$. 水酸化第一鉄との共沈，それに続 く topotactic な酸化, 沈殿の沪別という一連の過程に より, 様々な濃度そして温度の条件下で, 上記 6 種の金 属イオンは水中残存量 $0.01 \mathrm{ppm}$ 程度にまで除去される ことを著者らは見出している。

水酸化第一鉄は, その沈殿生成の際に水銀イオンに対 しても強い共沈効果を示す. 約 $48 \mathrm{ppm}$ 以下の $\mathrm{Hg}^{2+}$ の み含む水溶液は， $\mathrm{pH}$ 1〜14 の範囲で沈殿を析出しな い. また微酸々性において, $\mathrm{Hg}^{2+}$ の溶液に $\mathrm{Fe}^{2+}$ を加 えても反応は生じないことが知られている.しかし， $\mathrm{Hg}^{2+}$ と $\mathrm{Fe}^{2+}$ の混合溶液をアルカリ性にすると黒褐色 の強磁性沈殿 が析出し, 水溶液中の水銀濃度は約 0.06 $\mathrm{ppm}$ に減少する。このような共沈は, 少なくとも $\mathrm{Hg}^{2+}$ の水酸化第一鉄への置換固溶とは考えられず, 吸着ない し吸蔵でもない。しかも従来この共沈現象について検 討が加えられた形跡も見当たらない，検討の結果この共 沈現象は, 以下に述べるよらに水酸化第一鉄の沈殿析出 過程で酸化還元反応を伴う新しい共沈機構によるもので あることが明らかとなった。そして水溶液中に分散して いる水酸化第一鉄微結晶の酸化の過程を, 固液界面にお ける鉄イオンの動きとしてとらえ,この新しい共沈機構 について考察を加えた。

\section{2. 実験}

適量の $\mathrm{FeSO}_{4}$ および $\mathrm{HgCl}_{2}$ を室温で蒸溜水に溶解 する. その $100 \mathrm{ml}$ を取り, $1 \mathrm{~N}$ カセイソーダ水溶液を 擋拌しながら加え $\mathrm{pH}=10$ に調節する. 混合溶液中の $\mathrm{Fe}^{2+}$ および $\mathrm{Hg}^{2+}$ の濃度を $0.2 \sim 1.8 \mathrm{~m} \mathrm{~mol} \mathrm{および}$ $0.01 \sim 0.1 \mathrm{~m} \mathrm{~mol}$ にそれぞれ選んだ. 析出した共沈体を 含む分散溶液をさらに 15 分間擋拌し続けた後, 沪過し た. 沪液中の残留水銀量を還元気化法（標準添加法）に より原子吸光装置を用いて分析した。

全操作は室温で行い，また系の酸化を防ぐため純窒素 ガス中で行った．試料水溶液の作製にあたっては, 全て 3 回蒸溜水を, 使用直前に煮沸して使用した.

\section{3. 結 果}

図 1 に残留水銀濃度を示す.なお, $\mathrm{Fe}^{2+}$ の濃度を極

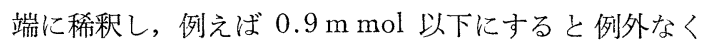
共沈効果が極めて悪くなるため, 検討の対象からは除い

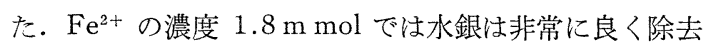

され，その濃度は 0.0003 0.0015 m mol に減少してい る. そこで $1.8 \mathrm{~m} \mathrm{~mol}$ 以上に $\mathrm{Fe}^{2+}$ の濃度を高めてみ たのであるが, 水銀の残留濃度は $0.0003 \mathrm{~m} \mathrm{~mol}$ が限度

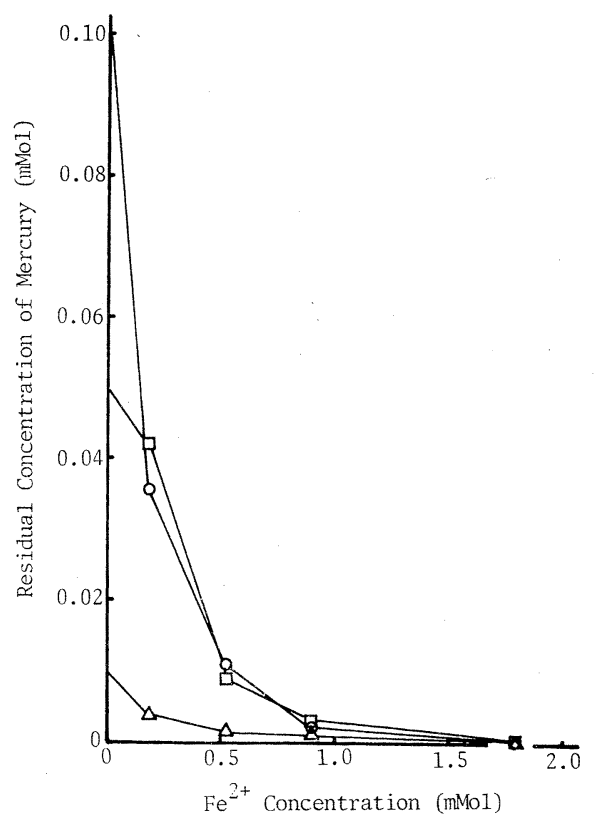

Fig. 1. Residual concentration of mercury vs. concentration of $\mathrm{Fe}^{2+}$. Initial concentration of $\mathrm{Hg}^{2+}$ of $0.01 \mathrm{~m} \mathrm{~mol} \mathrm{:} \triangle ; 0.05 \mathrm{~m} \mathrm{~mol} \mathrm{:} \square$; and $0.10 \mathrm{~m} \mathrm{~mol}: \bigcirc$.

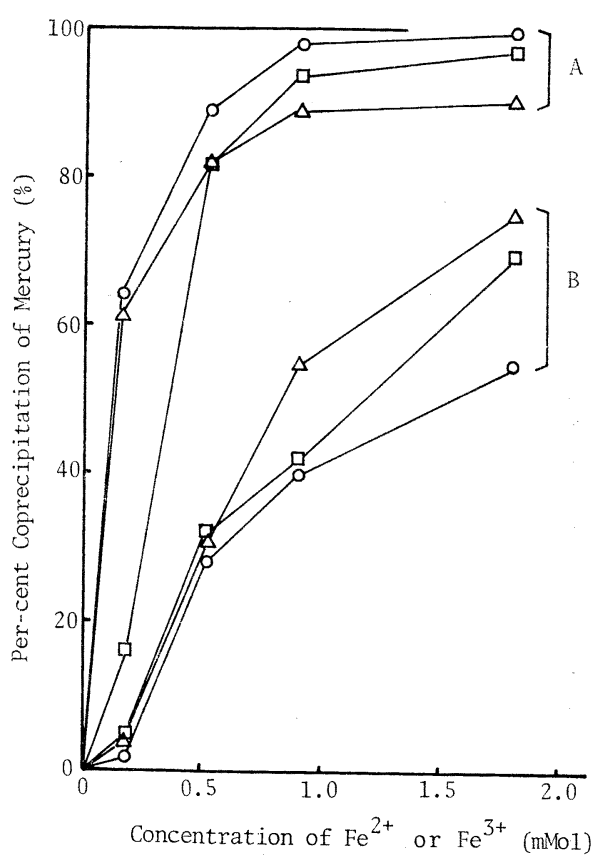

Fig. 2. Per-cent coprecipitation of mercury vs. concentration of $\mathrm{Fe}^{2+}[\mathrm{A}]$ or $\mathrm{Fe}^{3+}[\mathrm{B}]$. Initial concentration of $\mathrm{Hg}^{2+}$ of $0.01 \mathrm{~m} \mathrm{~mol} \mathrm{:} \triangle ; 0.05$ $\mathrm{m} \mathrm{mol}: \square$; and $0.10 \mathrm{~m} \mathrm{~mol} \mathrm{:} \bigcirc$. 
で，それ以下には減少しないことが認められた。この值 $0.0003 \mathrm{~m} \mathrm{~mol}$ は金属水銀の溶解度 $(\mathrm{pH} \simeq 10$ に拈いて $0.0003 \mathrm{~m} \mathrm{~mol}$ 又は $61 \mathrm{ppb}$ ) に極良く一致する ${ }^{5)}$.

図 2 は共沈率を示したものである. $\mathrm{Fe}^{3+}$ と $\mathrm{Hg}^{2+}$ の 混合溶液から沈殿を析出させた場合の共沈率も併せて示 した。 共沈率は $\mathrm{Fe}^{2+}$ の濃度 $1.8 \mathrm{~m} \mathrm{~mol}$ において最高 $99.7 \%$ にまで達しているが， $\mathrm{Fe}^{2+}$ の濃度をこれ以上濃 くしても，決して 100\% にはならなかった。また $\mathrm{Hg}^{2+}$ の初期濃度が薄い程, 共沈率は低下の傾向を示す．これ らは上述のよらに水銀の残留濃度に下限があるためであ る. $\mathrm{Fe}^{3+}$ にる共沈の場合には，共沈率は $\mathrm{Fe}^{3+}$ の配 合量が多い程増加する傾向は認められるが， $\mathrm{Fe}^{3+}$ の濃 度 $1.8 \mathrm{~m} \mathrm{~mol}$ においてその值は $75 \%$ にとどまり， $\mathrm{Fe}^{2+}$ の場合にくらべて $\mathrm{Fe}^{3+}$ の共沈能力が遥かに劣ることが 明らかである。また $\mathrm{Hg}^{2+}$ の初期濃度が小さい程共沈率 が高くなる傾向が認められる。こういった曲線の傾向か ら見て $\mathrm{Fe}^{3+}$ にる $\mathrm{Hg}^{2+}$ の共沈機構は吸着ないし吸蔵 と推量され，実際に新しい化合物の形成は検出されず, また固溶体の形成も考え難い.

図 3 は $\mathrm{Fe}^{2+}$ と $\mathrm{Hg}^{2+}$ との混合比に対する水銀の残 留濃度の変化を示したものである。 $\mathrm{Fe}^{2+}$ の初期濃度は

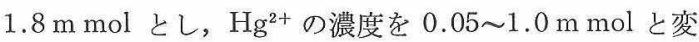
化させてある。図から明らかなよらに， $\mathrm{Fe}^{2+} / \mathrm{Hg}^{2+} \simeq 3$ の值を境にしてそれ以下では急激な水銀残留濃度の増加 を示している。この結果から見て，この場合の共沈は表 面吸着，吸蔵あるいは固溶体の形成などによるものとは 考えられず，化学反応が関与しているものと判断され る.

室温における X 線回折図形は，ゲル状共沈体がマグ ネタイトおよび水酸化第一鉄の混合物であることを示 し， $\mathrm{Fe}^{2+}$ の配合比功大きくなると $\mathrm{Fe}(\mathrm{OH})_{2}$ の X 線強 度比も増加する傾向が見られた．しかし結晶性の水銀化 合物の存在は検出されず，低角側での散漫散乱から金属

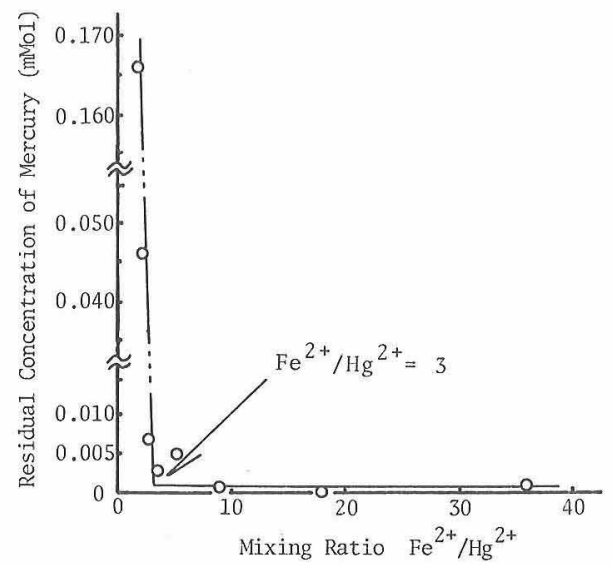

Fig. 3. Removal of mercury vs. mixing ratio $\mathrm{Fe}^{2+} /$ $\mathrm{Hg}^{2+}\left(\mathrm{Fe}^{2+}\right.$ concentration $=1.8 \mathrm{~m} \mathrm{~mol}$ ).
水銀の存在が疑われた. そこで非酸化性雾囲気中で処理 乾燥した共沈試料の $77 \mathrm{~K}$ における X 線回折図形を, 低温ワイセンぶルグカメラにより得た。図4から明らか に金属水銀の存在が検出された。つまり共沈過程で酸化 還元反応を伴うこと，そして溶液中の $\mathrm{Hg}^{2+}$ は $\mathrm{Hg}^{0}$ に 還元され， $\mathrm{Fe}(\mathrm{OH})_{2}$ はマグネタイトに酸化されること が明らかとなった。

図 5 はあらかじめ水酸化第一鉄の白色沈殿を析出させ ておき，その䊢濁液に $\mathrm{Hg}^{2+}$ 溶液を室温で混入，放置し た場合の水銀の除去率を，共沈の場合と比較した結果で ある。共沈の場合水銀の除去率はほぼ 100\% (99.7\%) であるが，単に混合しただけでも $\mathrm{Hg}^{2+}$ は $95 \%$ 以上の 割合で除去された。この反応は室温で迅速に進み，数分
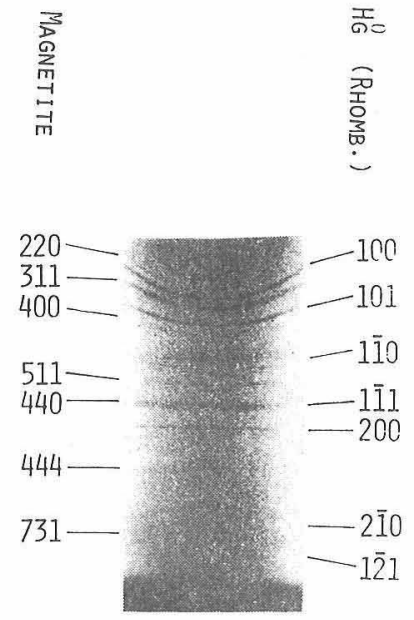

Fig. 4. Identification of metallic mercury in ferrous-mercuric coprecipitate.

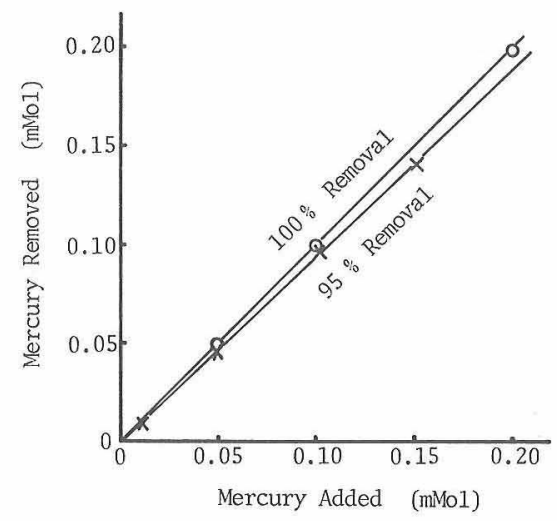

Fig. 5. The removal of $\mathrm{Hg}^{2+}$ by coprecipitation and adsorption.

0 : Coprecipitation from mixed solution containing a constant $1.8 \mathrm{~m} \mathrm{~mol} \mathrm{FeSO}_{4}$ and $\mathrm{HgCl}_{2}$ with concentrations ranging from 0.05 to $0.20 \mathrm{~m} \mathrm{~mol}$. $x$ : Adsorption by mixing $10 \mathrm{~m} \mathrm{~mol} \mathrm{HgCl}_{2}$ into $\mathrm{Fe}$ $(\mathrm{OH})_{2}$ suspensions prepared from $1.8 \mathrm{~m} \mathrm{~mol}$ $\mathrm{FeSO}_{4} \cdot \mathrm{HgCl}_{2}$ concentration in the suspensions ranged from 0.01 to $0.15 \mathrm{~m} \mathrm{~mol}$. 
間の放置で水酸化第一鉄の白色沈殿は次第に黒褐色の強 磁性体に変化する．つまり $\mathrm{Fe}(\mathrm{OH})_{2}$ 微結晶は $\mathrm{Hg}^{2+}$ に よりマグネタイトに酸化され，かつ金属水銀が生成する ものである。

\section{4. 考察}

酸性溶液中では $\mathrm{Fe}^{2+}$ と $\mathrm{Hg}^{2+}$ とを混合しても酸化還 元反応は生じない。しかしアルカリ性水溶液中では明ら かに酸化還元反応が進み，水酸化第一鉄はマグネタイト に酸化され， $\mathrm{Hg}^{2+}$ は金属水銀に還元される. 水酸化第 一鉄の強い還元作用によるものである. 多くの文献には 次の反応しか示されていない.

$$
\mathrm{Fe}(\mathrm{OH})_{3}+e^{-}=\mathrm{Fe}(\mathrm{OH})_{2}+\mathrm{OH}^{-}
$$

$E^{0}=-0.56 \mathrm{~V}$

しかし, 次式に示す反応の還元電位が遥かに大きい.

$$
\mathrm{Fe}_{3} \mathrm{O}_{4}+4 \mathrm{H}_{2} \mathrm{O}+2 e^{-}=3 \mathrm{Fe}(\mathrm{OH})_{2}+2 \mathrm{OH}^{-}
$$

$E^{0}=-1.025 \mathrm{~V}$

水銀の還元反応は次式で示される.

$$
\mathrm{Hg}(\mathrm{OH})_{2}+2 e^{-}=\mathrm{Hg}^{0}+2 \mathrm{OH}^{-}
$$$$
E^{0}=+0.098 \mathrm{~V}
$$

それ故, 次式の酸化還元反応の標準自由エネルギー変 化は $+51.8 \mathrm{kcal} / \mathrm{mol}$ となる ${ }^{6)}$.

$\mathrm{Hg}^{0}+\mathrm{Fe}_{3} \mathrm{O}_{4}+4 \mathrm{H}_{2} \mathrm{O}=3 \mathrm{Fe}(\mathrm{OH})_{2}+\mathrm{Hg}(\mathrm{OH})_{2}$

上式から明らかなように, 反応が量論的に進めば $\mathrm{Fe}^{2+} / \mathrm{Hg}^{2+}=3$ で完結する.実際に図 3 において, 混合 比約 3 を境にしてそれ以下では水銀の残留濃度が著しく 増加している.

アルカリ水溶液 $(\mathrm{pH} \geqq 10)$ に分散している $\mathrm{Fe}(\mathrm{OH})_{2}$ あるいはその置換固溶体 $\mathrm{Me}^{2+}{ }_{x} \mathrm{Fe}^{2+}{ }_{(1-x)}(\mathrm{OH})_{2}(\mathrm{Me}$ : $\mathrm{Mg}, \mathrm{Zn}, \mathrm{Cd}, \mathrm{Mn}, \mathrm{Co}, \mathrm{Ni}$ ) 酸化すると, 酸化の条件 により全く異なる反応生成物が得られる：(1) 室温付近 (約 $30^{\circ} \mathrm{C}$ 以下) で $\mathrm{H}_{2} \mathrm{O}_{2}$ 水溶液などで急速に酸化する と, $\delta-\mathrm{FeOOH}$ ないしその置換固溶体が形成され，(2) 比較的高温（約 $60^{\circ} \mathrm{C}$ 以上）で穏やかな酸化方法 $\left(\mathrm{KNO}_{3}\right.$ の添加あるいは空気酸化など）によると, マグネタイト ないしその置換固溶体が得られ, そして, (3) 室温付近 で穏やかに酸化する（例えば空気酸化）と， $\alpha-\mathrm{FeOOH}^{*}$ が主に生成されるが，本実験で示したようにマグネタイ 卜ないしその置換固溶体を生ずる場合もある。こうい。 た水酸化第一鉄微結晶から成る沈殿の, 酸化条件の微妙 な変化による酸化生成物の変化の原因は, 酸化還元反応 の機構が異なるためであり, その差異は微視的には反応 が起こる場所 “topos”が異なるためと解釈される.

酸化剂濃度が著しく濃い場合, 反応は水酸化第一鉄微 結晶の表面, 図 6 において Reaction site I で示され

* $\alpha-\mathrm{FeOOH}$ を母体とする置換固溶体に関しては，見るべき 報告がない，予備的な実験では， $\mathrm{Zn}^{2+}, \mathrm{Cd}^{2+}, \mathrm{Co}^{2+}, \mathrm{Ni}^{2+}$ などはほとえど固溶しない。
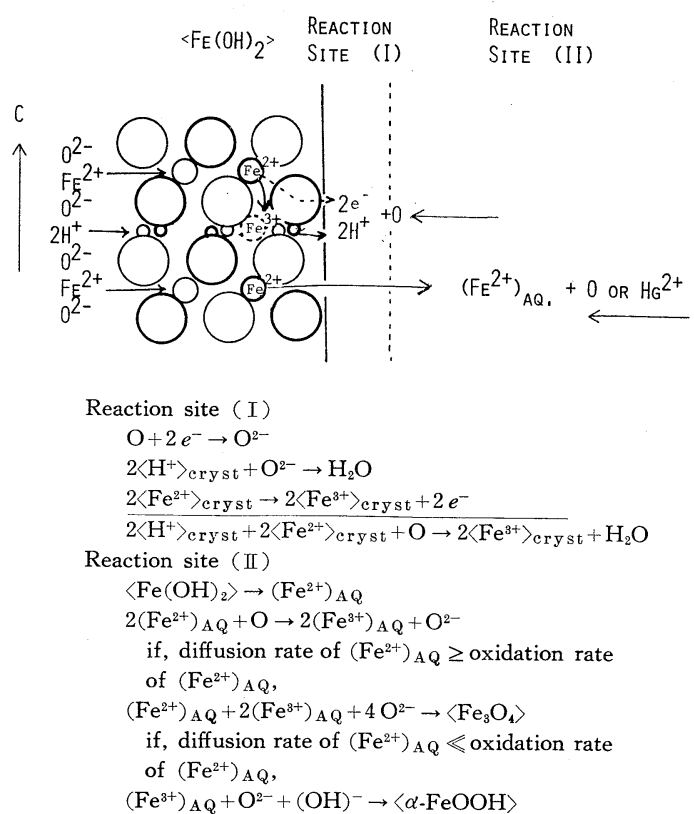

Fig. 6. Mechanisms of the redox reaction at ferrous hydroxide crystal-solution interface.

た場所で起こると考えられる。つまり酸化剤原子ないし イオンは直接微結晶表面に到達し, そこで結晶から電子 $e^{-}$とプロトン $\mathrm{H}^{+}$とを受け取り還元される. この間結 晶内部では, 酸化による鉄イオンの電荷の増加とプロ卜 ンの欠損とにより強い電場が生じ，このため鉄イオンの 一部は隣接するプロトン層に移動する*. しかし結晶構 造の枠組みを構成している $\mathrm{O}^{2-}$ は動かず，構造の基本 は変化しない，従ってこの種の反応は卜ポ化学的であ り，かつ topotactic である。これに対し，酸化剂濃度 が薄い場合, 反忘は微結晶表面から離れた溶液側, Reaction site II で示された場所で生ずると考えられ る.つまり, 酸化剤原子ないしイオンは, 微結晶表面に 到達する前に微結晶と平衡して溶存している $\mathrm{Fe}^{2+}$ $\left(\mathrm{H}_{2} \mathrm{O}\right)_{6}$ と反応するであろう。 もし酸化郕の補給が限ら れ, かつ微結晶側からの $\mathrm{Fe}^{2+}$ の補給が速やかな場合, $\mathrm{Fe}^{2+}$ と $\mathrm{Fe}^{3+}$ とが会合してマグネタイトを析出するで あろう。このような条件は酸化温度の高い, それ故 $\mathrm{Fe}^{2+}$ の溶解拡散が速く, 一方酸素の溶解度の低、場合と考え られ，実際に高温側でマグネタイトが優先的に析出す る.これに対し温度が低いと空気酸化では $\mathrm{Fe}^{3+}$ のみの 会合が生じて $\alpha-\mathrm{FeOOH}$ が晶出するであろう． $\mathrm{Fe}^{2+}$ の 濃度が薄くても酸化が穏やかであれば，結晶から $\mathrm{Fe}^{2+}$ が補給されるためマグネタイトが析出しうる。これら一 連の反応過程は，固体の変化を中心に見ると典型的な溶 解析出型の反応である.

\footnotetext{
*このため $\mathrm{Fe}^{3+}$ の再配列が生じ，結果的に各層ごとの $\mathrm{Fe}^{3+}$ の濃度が異なるため, 反応生成物である $\delta$ - $\mathrm{FeOOH}$ がフェ リ磁性を示すことになる.
} 
室温において水銀イオンは水酸化第一鉄により水銀に 還元され，一方水酸化第一鉄はマグネタイトに酸化され る. その機構は, 水酸化第一鉄微結晶の結晶界面におけ る溶液側 (Reaction site II) での反応と考えられる. 生じた $\mathrm{Fe}^{3+}$ は $\mathrm{Fe}^{2+}$ と会合してマグネタイトを生ず る. 図 3 の実験結果から明らかなように, この反応は定 量的に進む.

銅イオンも水酸化第一鉄と共沈するが，その機構は決 して置換固溶によるものではない，水銀イオンに抢ける と同様に, 酸化還元反応を伴う共沈反応であることが認 められる. $\mathrm{Cu}^{2+}$ に対しやや過剩の $\mathrm{Fe}^{2+}$ を配合した水 溶液に沈殿剤としてカセイソーダを加え $\mathrm{pH} 10$ に調節 する. 共沈ゲルの X 線図から $\mathrm{Cu}_{2} \mathrm{O}$ とマグネタイトの 生成が確認された。沪液中の残留銅濃度は, 様々な共沈 条件の下でほぼ $0.07 \mathrm{ppm}$ に減少していることが認めら れた。

銅イオンと水酸化第一鉄との共沈の際にアンモニアを 沈殿剤として用いると，銅イオン濃度が比較的薄い（例 えば数 $\mathrm{mmol}$ 以下) 場合，マグネタイトおよび金属銅
の析出が認められた．ただしこの場合の共沈効果は不充 分で, 銅イオンは銅アンミン錯体としてかなり水溶液中 に残留する．濃厚な銅シアン錯体水溶液の過剩を，あら かじめ調節した水酸化第一鉄沈殿の分散溶液に室温で加 えると, 銅イオンの一部は金属銅に還元され，水酸化第 一鉄は $\delta-\mathrm{FeOOH}$ に酸化される. 水酸化第一鉄微結晶 表面で $\mathrm{Cu}^{2+}$ が金属銅に接触還元され，水酸化第一鉄は topotactic に $\delta-\mathrm{FeOOH}$ に酸化されるものと判断され る.

\section{文献}

1) 例光ば, W.M. Garrison, J.G. Hamilton, Chem. Rev., 49, 237-72 (1951).

2) S. Okamoto, IEEE Trans. on Magnetics, MAG10, 923-26 (1974).

3) 岡本, セラミックス, 11, 234-41 (1976).

4) 岡本, 工化, 67, 1855-60 (1964).

5) E. Onat, J. Inorg. Nucl. Chem., 36, 2029-33 (1974).

6) 例えば, M. Pourbaix, “Atlas D'equilibres Electrochimiques”, Gauthier-Villars S Cie. (1963), Paris, p. 307, p. 421.

7) S. Okamoto, J. Am. Ceram. Soc., 51, 594-99 (1968).

ノート・ Note

\title{
Self-Diffusion Coefficient of Oxygen in Vapor-Grown Single Crystal Alumina
}

\author{
Yasumichi OISHI, Ken ANDO and Keiji MATSUHIRO \\ (Department of Nuclear Engineering, Faculty of Engineering Kyushu University, Fukuoka-shi, 812)
}

[Received April 30, 1977]

\section{気相法単結晶アルミナ中の酸素の自己拡散係数}

\author{
大石行理・安藤健・松広啓治 \\ (九州大学 工学部 応用原子核工学教室)
}

(4/30/1977 受付)

\section{Introduction}

The self-diffusion coefficient of oxygen in a single crystal alumina was first reported by Oishi and Kingery ${ }^{1)}$. Their specimen was a single crystal made by the Verneuil technique and showed two different regimes of the self-diffusion depending on the temperature range. The high temperature regime with an activation energy of
$152 \mathrm{kcal} / \mathrm{mol}$ was interpreted as being due to intrinsic self-diffusion and the low temperature regime with $57.6 \mathrm{kcal} / \mathrm{mol}$ due to extrinsic selfdiffusion. They suggested the mechanism of the extrinsic diffusion was conceivably impurity-controlled or structure-sensitive, but it was not elucidated which was the case.

Since then single crystal alumina of high purity 